\title{
IDEOLOGY AND POWER IN THE AGE OF LENIN IN RUINS
}

\author{
Arthur and Marilouise Kroker
}

\section{When the Berlin Wall Finally Came Tumbling Down}

What is the fate of ideology and power in the age of Lenin in ruins? Now that bureaucratic socialism stands unmasked as an actually existing ideology of state domination in all of the societies of Eastern Europe, what is the destiny of Marx's understanding of ideology as only a falsification of capitalist relations of production? And now that power in Western Europe and North America dissolves into the sign of seduction, what is to be the fate of the political subject, outside, that is, the closed horizon of both techno-capitalism and socialist realism. When the Berlin Wall finally came tumbling down, all of the old comfortable markers of political debate suddenly shattered, revealing in its wake a desperate urgency to rethinking the meaning of ideology and power in a world dominated by the eclipse of the political legitimation of state socialism and by the seeming triumph everywhere now of the rituals of primitive capitalism. The East goes Thatcherite; the West goes Green; and the United States goes virtual (technology).

\section{Lenin in Ruins}

If the twentieth century can be plunging towards its conclusion with such violent energy, that is because we witness now the simultaneous decomposition and success of its two founding moments: the search for materialist freedom and for collective justice. Not decline in the traditional sense of a final catastrophe which marks the end of one historical epoch and the beginning of another, but a new historical mode of transformation-hyper-decline-in which communism and capitalism can exist now as pure forms: stripped of their illusions and unmasked of their interests. Historical manifestations, that is, of what Pietr Sloterdijk has described in the Critique of Cynical Reason as "enlightened false consciousness." The $m y$ ths of communism and capitalism, then, as floating signs-degree zero-points-for the cancellation and imminent reversibility of all the polarities: the mutation of the (socialist) struggle for justice into cynical power; and the materialist dream of the (iberal) flight from politics into the triumph of cynical ideology. Like "strange attractors" in astrophysics which can exercise such a deadly fascination because of their ability to alternate energy fields instantly, the myths of state capitalism and state communism are alternat- 


\section{LENIN IN RUINS}

ing sides of the rationalist eschatology: the symptomatic signs of the appearance of the bimodern condition.

Bimodernism? That is the contemporary historical situation in which the great referential polarities instantly reverse fields, changing signs in a dizzying display of political repolarization. A violent metastasis in which all the referential finalities of the political code of the twentieth century-capitalism and communism most of all-begin to slide into one another, actually mutating into their opposites as they undergo a fatal reversal of meaning. No longer justice versus the acquisitive instinct, power versus ideology, (socialist) history versus (consumer) simulation, or (economic) liberalism versus (political) democracy, but now the instant reversibility of all the referents. A fatal eclipse of the empire of the sign in which capitalism and communism do a big historical flip. Not just the myth of capitalism in desperate need of the communist "other" to sustain itself or communism as a barrier against the universalization of the commodity-form, but now communism aping the economic form of primitive capitalism, and capitalism taking on the political form of the command economy of late communism. The capitalist societies, then, as the forward frontier of the communist valorization of power; and communist societies as the last and best of all the primitive capitalisms. In one, the inspiring faith in commercial accumulation and the resucitation of law of value of the production machine; and in the other, the radical depoliticization of the population, its actual body invasion, by a totalitarian image-reservoir under the control of a cynical political mandarinate. In one, the recuperation of the productivist myth of Franklin Delano Roosevelt as a policy of economic reconstruction; and in the other, the Leninist use of all the mass organs of media manipulation as a way of coordinating private opinion with the war machine.

- So then, Spengler again: but this time the ecstacy of the decline of the West. The history of two familiar genocides: of the (capitalist) logic of exterminism in the name of reason; and of (communist) murder in the name of collective justice.

Not capitalism and communism as fatal antagonists, but as the deepest fulfillment of the dream of the West: the dream, that is, of the universalization of the rationalist eschatology as the radiating code of politics, economy, culture and subjectivity. The one the history of the individual search for commercial freedom under the sign of missionary consciousness; the other the struggle for social justice under the code of historical materialism. The first, the penetration of subjectivity by the language of the technological dynamo; the second, the externalization of subjectivity into the public orthodoxies of socialist realism. The one a daring, but ultimately futile attempt, to mute the leviathan of politics by making democratic aspirations subordinate to liberal capitalism; the other a revolutionary effort to suppress ideology in the name of power. A history, that is, of a fatal dedoublement in the Western mind which, playing on the more ancient philosophical terrain of justice and freedom, created, and then destroyed, within the space of a single century two deeply entangled myths. On the one hand, the communist myth, scientistic in the extreme and ruggedly materialistic in its practice, which stood (and fell) on the possibility of subordinating the demon of capitalist desire to the historical sovereignty of the State. And; on the other, the 


\section{IDEOLOGY AND POWER}

capitalist myth, individualistic in .its genealogy and contractual in its social execution, which held out the possibility of maximizing human freedom by bringing the object alive, by, that is, creating a system of objects in which liberty would accrue to the physics of market exchanges. Like all myths which seek to solve the riddle of history, the myths of capitalism and communism suffer, in the end, the desolation of a purely aleatory fate: in all the socialist societies, the state acquires organicity; it actually comes alive in the political form of what Sartre has called "The Thing"-cynical ideology-and eats its political subjects; and, in the capitalist societies, the object comes alive in the consumer language of seduction-cynical power-and, like a radiating positivity, first eats space and time, and then consumes subjectivity itself. The historical myths of capitalism and communism as both suffering a common biological denouement: two big eating machines which require for their operation the radical depoliticization of the population, the softening up of the masses, that is, as a prerequisite to the libidinal feast of cynical power and cynical ideology. What Heidegger once prophecied would be the triumphant appearance of the dark language of "harvesting"-the will to exterminism-of the living energies of social and nonsocial nature as the primal of twentieth century politics.

\section{The End(s) of History}

In Modris Ekstein's Rites of Spring, it is recounted how during the trench warfare of World War I soldiers from both sides began on occasion to actually live in no man's land, that indefinite terrain which, belonging to no one, became a privileged imaginary country in opposition to the ruling empires of the war machine. When this was discovered, the opposing General Staffs, both German and British, immediately ordered the shelling of these troops, finding in their neutral presence an imminent threat to the sovereignty of the great political signifiers of the war machine.

This text consists of theorists of no man's land, occupants of the deterritorialized terrain of the intellectual imagination: standing midway between the epochal referents of power and ideology. While they have real theoretical differences, they commonly share the position of intellectual witnesses to the transformation of the politics of the rationalist eschatology at the end of the century. Their writings are like explosive blasts from the pent-up pressures of the weak points of the war machine: points of tension which are so unreconciled in politics and economy, that they find finally a theoretical purchase.

Ideological blasts, as in the case of the writings of-Giddens, Habermas, Márkus, Baumann, Laclau and Lefort: theorisations written in the shadow of Marxism where the irreconcilability of democracy and state capitalism are put into question. Here, the political history of the twentieth century is rewritten by connecting anew the question of ideology to the reality of domination.

Power blasts, written with and against the theorisations of Jean Baudrillard, where the concern is not so much with the end(s) of history as with the final declaration of the end of history: the death of history, and of politics and society 


\section{LENIN IN RUINS}

with it, as the question of ideology is sucked, like so much floating debris in the dark matter of political space, into the black hole of cynical power.

And finally, culture blasts-the final section on Demon Politics-where the epochal retheorisations of ideology and power are materialized in specific contestations with actually existing political culture. Here, the explosive energy of the theoretical imagination is poured into an examination of the ruling political questions: ressentiment as the basis of contemporary politics; the resurfacing of the Hobbesian calculation as the (fading) essence of American political experience; the materialization of Heidegger's "will to exterminism" as the dynamic language of liberalism today; and finally, the enucleation of women within a labyrinth of signification, which, just as Anthony Giddens predicted, reconnects the questions of ideology and domination.

More than a rereading of the central concepts of power, ideology and culture, the theorisations in this text have an epochal significance in representing the ways in which critical thinkers, writing at the fin-de-millenium, have chosen to represent the political history of the twentieth century. Here, we are confronted with three alternative histories of the contemporary century: one written under the sign of a revalorized theory of ideology; the second inscribed in the language of cynical power; and the third focussing directly on the problematic terrain of culture.

Indeed, it may well be said someday of that critical arc of neo-Marxist theorists, ranging from Giddens and Laclau to Habermas and Lefort, that, aside from sectional differences, their writings bring to a brilliant conclusion the myth of modernism, so integral to Marxian eschatology. Here, in a return to the original Marxian impulse to think ideology politically by reconnecting it to political economy, sometimes as "false consciousness" and at other times as the inscribed horizon of the law of productivist value, these theorisations repoliticize ideology by linking it to a searing analysis of the signifying practices and systemic requirements of state capitalism. Here, the Marxian project of "demystifying history" by reinverting the camera obscura is thought with such political intensity that the question of ideology itself is uprooted from its previous position as the transparent horizon of class domination, becoming now a critical agent in teasing out the dominations and dependencies of the system of capitalist political economy. Or, as Giddens says: "The forms of ideology are very often the modes in which signification is incorporated as part and parcel of what one does in daily life." Operating then within the parameters of the law of value, the theories of ideology represented here foreground the question of human freedom against the background of the mirror of political economy. And if they can so universally concur in the politics of democratic assent, that is because these are the last and best of all the enlightenment thinkers: intellectuals of the late twentieth century who seek to repair the broken connection of labor, reason and politics, so darkly prophecied in all of Marx's writing on the capitalist expropriation of the enlightenment dream. Rethinking ideology and domination, therefore, as a more elemental intellectual drama in which the great polarities of the dialectic of enlightenment are brought into violent collision, with the fate of democracy hanging in the balance. 


\section{LENIN IN RUINS}

depolicitized mass, wavering between the sleep of "mechanical forgetting" and the sacrificial violence of revenge-seeking behavior. A deeply sacrificial culture which is bimodern to this extent: it exists midway between hyper-primitivism of emotions and hyper-rationalism of its controlling codes. And not a projective culture either, but one which traces a great arc of reversal: a reversion of the rationalist eschatology to its primal origins in myth; of ideology to its foundations in cynical truth; and of power to a sacrificial table of values, alternating the positions of predators and parasites.

Consequently, a third history of the twentieth century: one which does not contradict the reconnection of ideology and domination or the unmasking of cynical power, but accelerates them to such a point of violent intensity that they achieve escape velocity, revealing thereby politics at the fin-de-millenium as a historic wager between subjugated knowledge and cynical power.

\section{The New World Order}

If the debates among ideology (modernism), power (postmodernism) and sacrifice (bimodernism) can rehearse so well some of the main currents of critical thought in the contemporary century, that is probably because these theoretical perspectives have a purchase on the political imagination which is more projective than retrospective. Like an immense gravitational field swept into the dark vortex of the Year 2000, the theorisations of ideology, power and sacrifice retreat ahead of politics, denominating all the while the political architecture of the future. Not so much, then, a summary of key controversies in fin-demillenium thought, but an early warning system of major transformations in international politics.

Maybe it is not so much Lenin in ruins now as the world in ruins. Not just the fall of the Berlin Wall as a fatal sign of the disintegration of Soviet empire, but as a talisman of the decline of American empire. The fatal loss, that is, with the unmasking of the myth of communist hegemony of the privileged object of sacrificial violence-the mimetic "Other"-which performed the honorific religious function of scapegoat for the burnout of the American mind.

But not for long. As a dazzling symbol of the triumph of alterity, a great magnetic shift of political fields takes place, with an instant mutation of East/ West conflict to a new cold war of North against South. The Gulf War, that is, as a field of sacrificial violence for the violent regeneration of American politics, and for reaffirming faith in the equivalence of freedom and technology-the civil religion of America. What Habermas once described as the "glassy background ideology" of technology now mutates into the guiding principle of the vaunted "new world order:" George Bush's term for the coming to be of Hegel's universal and homogenous state under the hegemonic sign of the technological dynamo.

The Gulf War, therefore, as a grisly replay of the medieval crusades. A final war in which, as the French theorist Paul Virilio states in Pure War, there is a conjunction of the Holy War (of religious fundamentalists) and of the Just War (of the nuclear technicians). 
A war which can be fought at the geographical meeting-point of the Tigris and Euphrates Rivers as if to emphasize that this is an epochal drama: the imminent reversal of the always projective logic of the West back to its primal origins in Mesopotamia. A religious war between Virilio's "dromocratic" war machine, the most intensive expression possible of the dream of the rationalist eschatology, and, in distorted form, the new "Other" of Arab nationalism. The world's first purely designer war: a promotional war machine which scripts in advance the whole metastasis of violence as an advertising campaign for the technological invincibility, and thus political necessity, of the "new world order."

The scene of a fatal decomposition in which all of the political tendencies from the past-ideology, power and sacrifice-rush towards their violent climax in purely inverted form: cynical ideology, cynical power, and cynical sacrifice. Consequently, the debates in Ideology and Power in the Age of Lenin in Ruins have, beyond their theoretical divisions, a broader literary significance as harbingers of the main contours of the nihilistic politics of the twenty first century. Third millenium politics, therefore, not as a time of cold seduction versus command socialism, but of a new world order which can be so deeply sacrificial because it is all about the harvesting of the energies of the social and the non-social universes by the "dromocratic" war machine. A time of the unmasking of ideology as domination, of power as a trompe-l'oeil of the cynical sign, and of sacrifice as mimetic violence against an "Other" which has only the irreal and projected existence of a frenzied political fantasy. 